\title{
The influence of urban agglomeration on a small natural water reservoir
}

\author{
Tadeusz Sobczyński ${ }^{\star}$ Przemysław Niedzielski \\ Adam Mickiewicz University in Poznań, Faculty of Chemistry, Umultowska 89b, 61-614 Poznań, Poland, e-mail: sobczyn@amu.edu.pl \\ ( ${ }^{*}$ corresponding author), pnied@amu.edu.pl
}

\begin{abstract}
The aim of the study was to determine the influence of urban agglomeration on a small, natural water reservoir which, as a result of the expansion of the city of Poznań, has become an urban lake. In the vegetation period 2015, the chemistry of its water was studied, and in September additional samples of bottom sediments, plants and fish were collected for analysis in order to determine the content of heavy metals. In terms of productivity, no significant influence of the catchment was recorded. In the 1980s the lake was defined as eutrophic, and in 1996 as a-mesotrophic and such a state continues until today. This is the result of protective activity undertaken by its new owner. The adverse influence of the urbanization of the surrounding areas was reflected by the increased content of lead in particular elements of this ecosystem, that is, in bottom sediments, plants and fish muscles.
\end{abstract}

Key words: small lake, urban agglomeration, anthropopression

\section{Introduction}

The significance of small reservoirs is often underestimated despite the fact that they influence the microclimate, regulate water relations, contribute to preserving valuable vegetation and provide a habitat for many animal species, especially birds. They are usually midfield water bodies, but the expansion of urban agglomerations sometimes causes their transformation into urban reservoirs (Paturej 2008). In such cases they not only serve nature-related and climatic functions but they are also important for the community, providing areas of nature which foster leisure activities and relaxation and ensure direct contact of the inhabitants with nature.

Changing the surroundings of these reservoirs from agricultural to urban areas also affects catchment impacts on water quality (Bedla and Misztal 2014). However, due to their small size, these reservoirs are not included in the National Environmental Monitoring System and, as a result, the knowledge about their condition is either very basic or they are completely omitted in scientific research.

The aim of this study was to assess the influence of the Poznan city agglomeration on the chemistry of water of Lake Umultowskie - the smallest natural reservoir located within the city boundaries.

\section{Study area}

Lake Umultowskie $\left(52^{\circ} 28^{\prime} 33^{\prime \prime} \mathrm{N}, \quad 1^{\circ} 56^{\prime} 15^{\prime \prime} \mathrm{E}-\right.$ Poznań Lakeland) is located in the northern part of Poznan (a city in the west part of Poland, the area of the agglomeration covers $262 \mathrm{~km}^{2}$, with nearly 550 thousand inhabitants), in an area dominated by single-family housing. It is a small, post-glacial moraine reservoir, almost circular in shape, comprising an area of 3.1 ha. The maximum depth of the lake slightly exceeds $4 \mathrm{~m}$ (the $5 \mathrm{~m}$ deepest point was not found), and its average depth is $3.1 \mathrm{~m}$ (Fig. 1). It has a catchment area $0.7 \mathrm{~km}^{2}$, and its influence on the ecosystem is characterized by a Schindler coefficient of 7.5.

The bottom of the reservoir is covered by dense meadows of Ceratophyllum demersum L. and Myriophyllum spicatum L. The lake is surrounded by a belt of Phragmites australis (Cav.). On the western side, adjacent to the lake are wetland areas, also overgrown by reeds, opening out into thickets. In the east, the lake is surrounded by single-family detached houses.

Studies of Lake Umultowskie, conducted since 1979 by Krasko and Szyszka (1985), have shown its eutrophic character. Based on the results of studies conducted in the years 1990-1994, the quality of its water was classified as 2 nd quality class, in accordance with 

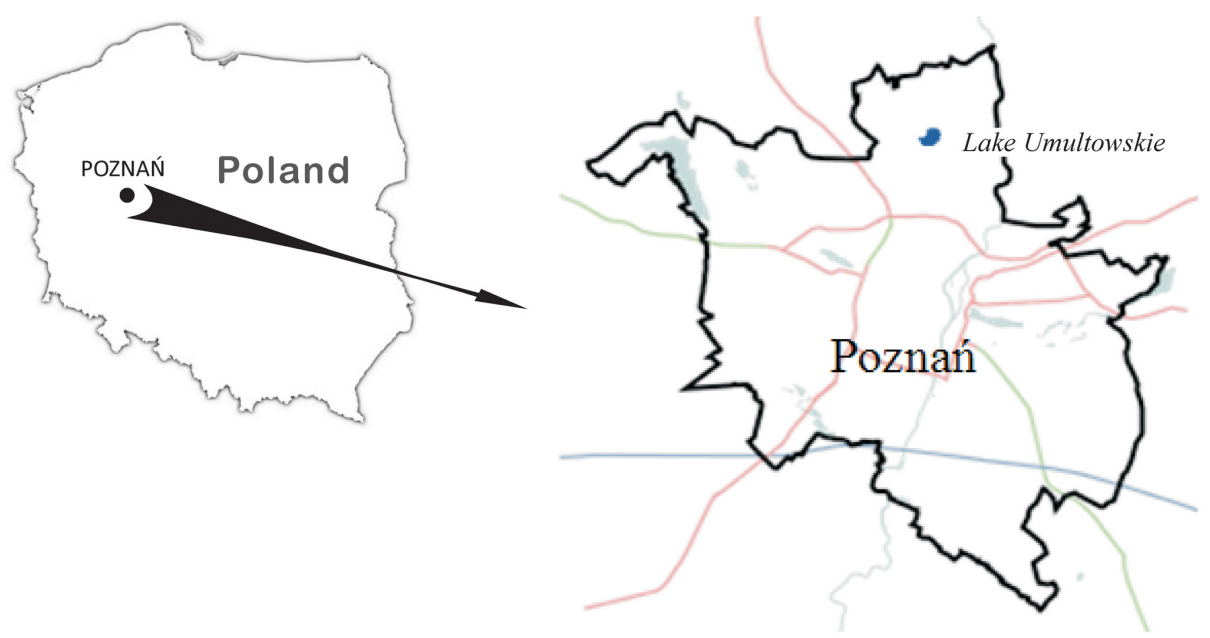

Fig. 1. Location of Lake Umultowskie in the city of Poznań

the three-class classification used at that time (Gołdyn et al. 1996). Carlson's trophic state index calculated in the summer of 2006 (Klimaszyk 2006) indicated that the lake is $\alpha$-mesotrophic. The studies of phytoplankton conducted at the same time found that the lake is of significant ecological value and should be protected (due to its biodiversity despite the lack of unique species) (Celewicz-Gołdyn and Klimko 2008).

In 1994, Lake Umultowskie and the surrounding area were placed under protection as Ecological Land comprising a total area of 18 ha. Unfortunately, this protection was withdrawn under the Act of 7 December 2001 when the Act of Environmental Protection (Polish Journal of Laws of 2001, No. 3 item 21), was amended; the Ecological Land Lake Umultowskie ceased to be covered by this form of protection by administrative decision (Urbańska et al. 2015).

Lake Umultowskie is a private property. In former years it has been intensively used by the nearby inhabitants for angling. This has resulted in the destruction of reeds surrounding the reservoir and increased littering of the surrounding area. Recently, however, the land owner radically restricted access to the lake for anglers and the source of biogenic elements - bait thrown in by the anglers - was almost totally cut off. At the same time, the reeds surrounding the lake were protected from destruction.

\section{Methods}

The studies of Lake Umultowskie were conducted during the vegetation period, from May to October, 2015. Taking into consideration the small area of the reservoir, one sampling point was located in the central part and the analysis was made in triplicates.

Visibility of was determined using a Secchi disc, while in the vertical profile the temperature and $\mathrm{pH}$ were measured every one metre from the surface to the bottom with a WTW 350i meter (WTW Germany). At the same time, a water sample was taken for laboratory tests from the depth of $0.3 \mathrm{~m}$. In this sample the following values were determined: $(i)$ anions $\left(\mathrm{Cl}^{-}, \mathrm{SO}_{4}^{2-}, \mathrm{NO}_{2}^{-}\right.$ , $\mathrm{NO}_{3}^{-}, \mathrm{PO}_{4}^{3-}$ ) with the ion chromatography method, using an 883 Basic IC plus chromatograph (Metrohm, Swiss), (ii) selected metals (Ca, Cd, Cr, Cu, Ni, Pb, Zn) with the ICP-OES method, using an Agilent ICP-OES 5110 instrument (Agilent, USA), and (iii) $\mathrm{NH}_{4}^{+}$ion, using colorimetry with Nessler's reagent.

The following values were also determined in the samples: (i) total phosphorus, after mineralization, using the molibdenian method (Hermanowicz 1999), (ii) dissolved oxygen, using a YSI ProODO oxygen meter with an optical ProOBOD probe (YSI, USA), (iii) biochemical oxygen demand ( $\left.\mathrm{BOD}_{5}\right)$, using an oxygen probe (YSI, USA), and (iv) alkalinity $\left(\mathrm{HCO}_{3}^{-}\right)$, using the titration method (Hermanowicz 1999).

Additionally, samples of bottom sediments were collected in September from six sites as well as plant samples and samples of muscles from above the side line of the caught fish in order to determine the content of selected metals. Sediment samples were taken with a tube sampler from six sampling points located regularly. Form studies of the top $10 \mathrm{~cm}$ layer of sediments were used. For plant analysis the above ground parts were first dried and then homogenised and the analytical sub-sample mineralised. Fish tissues were dried and melted. The samples were wet mineralized using $65 \%$ nitric acid in a closed system, in a CEM Mars 6 microwave mineralizer. In the obtained solutions, metals were determined by the MIP-OES method using an Agilent MP-AES 4200 spectrometer.

Hydration, percentage contents of organic matter (Bolałek 2010), and total contents of phosphorus were determined in bottom sediments. Phosphorus fraction- 
ation was also conducted using the sequential extraction scheme by Psenner (Psenner et al. 1988; Sobczyński and Joniak 2009) in order to assess the possibility of its release from bottom sediments to the water depth.

\section{Results and discussion}

The thermal properties of Lake Umultowskie - a small and relatively shallow water reservoir - changed significantly under the influence of sun (Table 1). In this polymictic lake in the months of May, June and August, a larger temperature drop was only observed in the over-bottom layer, indicating the formation of a small thermocline.

In July, when water clarity decreased, its saturation with oxygen increased significantly and a drop in alkalinity was recorded (Table 2), which was the consequence of more intensive growth of phytoplankton. The determined temperature profile indicated the temporary formation of thermal stratification with clearly marked epilimnion and thermocline. In August, when the influence of sun was less intense, this stratification disappeared. The vertical distribution of $\mathrm{pH}$ was very similar to the temperature profiles. During the whole study period (vegetation period) no high alkalization of water was observed and a maximum $\mathrm{pH}$ of 8.20 was determined, which expressly indicated that the blooming of phytoplankton was not too intensive during all that period. In the eutrophic Lake Góreckie $\left(52^{\circ} 15^{\prime} 46^{\prime \prime} \mathrm{N}\right.$, $16^{\circ} 47^{\prime} 53^{\prime \prime E}$ - Poznań Lakeland), located in the area of the Greater Poland National Park, the $\mathrm{pH}$ of epilimnion water was as high as 8.9 in the vegetation period and its saturation with oxygen was at the level of $132 \%$ (Sobczyński and Joniak 2008) reaching a maximum of 160\% (Sobczyński and Joniak 2013). Also in the shallow, urban Lake Jelonek in Gniezno (52 $32^{\prime} 04^{\prime \prime} \mathrm{N}$, $17^{\circ} 35^{\prime} 17^{\prime \prime E}$ - Greater Poland Lakeland) the level of dissolved oxygen was $14.8 \mathrm{mg} \mathrm{O} \mathrm{dm}^{-3}$ (approx. $165 \%$ saturation) (Niedzielski et al. 2007).

Throughout the whole period the lake water contained ammonium nitrogen, and, with the exception of July and August, also nitrate nitrogen (Table 3). Similar trends were observed in ponds located in the area of Poznań (Szpakowska et al. 2005).

The highest concentrations of nitrates, as well as total phosphorus and partly potassium were observed in June. On its eastern side the lake is surrounded by houses situated among beautifully maintained greenery. The incidental increase in concentrations of biogenic substances was caused by fertilizers flowing from the estates, commonly used in that period.

The factor limiting primary production in Lake Umultowskie was phosphorus, whose bio-available, inorganic forms occurred throughout the whole vegeta-

Table 1. Seasonal changeability of temperature $\left({ }^{\circ} \mathrm{C}\right)$ and $\mathrm{pH}$ in Lake Umultowskie within depth profile

\begin{tabular}{|c|c|c|c|c|c|c|c|c|c|c|c|c|}
\hline \multirow{2}{*}{ Depth } & \multicolumn{2}{|c|}{ May } & \multicolumn{2}{|c|}{ June } & \multicolumn{2}{|c|}{ July } & \multicolumn{2}{|c|}{ August } & \multicolumn{2}{|c|}{ September } & \multicolumn{2}{|c|}{ October } \\
\hline & Temp. & $\mathrm{pH}$ & Temp. & $\mathrm{pH}$ & Temp. & $\mathrm{pH}$ & Temp. & $\mathrm{pH}$ & Temp. & $\mathrm{pH}$ & Temp. & $\mathrm{pH}$ \\
\hline $0 \mathrm{~m}$ & 13.4 & 7.83 & 19.2 & 8.08 & 23.8 & 8.08 & 20.0 & 8.10 & 16.1 & 8.13 & 8.5 & 8.20 \\
\hline $1 \mathrm{~m}$ & 13.4 & 7.90 & 19.2 & 7.94 & 23.9 & 7.94 & 20.0 & 8.0 & 16.1 & 8.06 & 8.5 & 8.00 \\
\hline $2 \mathrm{~m}$ & 13.4 & 7.90 & 19.2 & 7.84 & 22.6 & 7.84 & 19.5 & 7.89 & 16.1 & 7.93 & 8.5 & 7.85 \\
\hline $3 \mathrm{~m}$ & 13.3 & 7.84 & 18.8 & 7.66 & 20.8 & 7.66 & 18.7 & 7.67 & 16.1 & 7.68 & 8.5 & 7.67 \\
\hline $4 \mathrm{~m}$ & 11.1 & 7.52 & 15.7 & 7.30 & 18.6 & 7.30 & 17.6 & 7.35 & 16.0 & 7.41 & 8.5 & 7.60 \\
\hline
\end{tabular}

Table 2. Seasonal changeability of physical and chemical parameters of water quality in Lake Umultowskie (mean values and standard deviations)

\begin{tabular}{|l|c|c|c|c|}
\hline \multicolumn{1}{|c|}{ Month } & Secchi disc $[\mathrm{m}]$ & Oxygen saturation [\%] & $\mathrm{BOD}_{5}\left[\mathrm{mg} \mathrm{O}_{2} \mathrm{dm}^{-3}\right]$ & Alkalinity [meq] \\
\hline May & 1.60 & 87.0 & $3.8 \pm 0.3$ & $4.00 \pm 0.05$ \\
\hline June & 1.90 & 85.0 & $4.0 \pm 0.3$ & $3.85 \pm 0.05$ \\
\hline July & 1.55 & 118 & $3.3 \pm 0.2$ & $3.65 \pm 0.05$ \\
\hline August & 1.55 & 108 & $3.4 \pm 0.2$ & $3.65 \pm 0.05$ \\
\hline September & 1.65 & 90.2 & $3.3 \pm 0.2$ & $3.75 \pm 0.05$ \\
\hline October & 2.80 & 88.3 & $1.5 \pm 0.2$ & $3.90 \pm 0.05$ \\
\hline
\end{tabular}

Table 3. Seasonal changeability of concentrations of biogenic substances in Lake Umultowskie water (mean values, RSD $<5 \%$ )

\begin{tabular}{|l|c|c|c|c|c|c|}
\hline \multicolumn{1}{|c|}{ Month } & $\mathrm{NH}_{4}^{+}\left[\mathrm{mg} \mathrm{dm}^{-3}\right]$ & $\mathrm{NO}_{3}^{+}\left[\mathrm{mg} \mathrm{dm}^{-3}\right]$ & $\mathrm{PO}_{4}{ }^{3-}\left[\mathrm{mg} \mathrm{dm}^{-3}\right]$ & $\mathrm{TP}\left[\mathrm{mg} \mathrm{dm}^{-3}\right]$ & $\mathrm{K}^{+}\left[\mathrm{mg} \mathrm{dm}^{-3}\right]$ & $\mathrm{Ca}^{2+}\left[\mathrm{mg} \mathrm{dm}^{-3}\right]$ \\
\hline May & 0.58 & 0.94 & $<0.05$ & 0.096 & 7.98 & 78.9 \\
\hline June & 0.57 & 2.86 & $<0.05$ & 0.161 & 8.34 & 80.2 \\
\hline July & 0.29 & $<0.01$ & $<0.05$ & 0.071 & 1.91 & 46.4 \\
\hline August & 0.27 & $<0.01$ & $<0.05$ & 0.079 & 1.81 & 46.7 \\
\hline September & 0.25 & 0.03 & $<0.05$ & 0.091 & 1.17 & 41.0 \\
\hline October & 0.19 & 0.90 & $<0.05$ & 0.053 & 4.41 & 87.6 \\
\hline
\end{tabular}


Table 4. Basic composition of bottom sediments

\begin{tabular}{|l|c|c|c|c|c|c|}
\hline \multicolumn{1}{|c|}{ Parameter } & Site1 & Site 2 & Site 3 & Site 4 & Site 5 & Site 6 \\
\hline Hydration [\%] & $91.4 \pm 1.8$ & $94.5 \pm 1.9$ & $95.3 \pm 1.8$ & $92.6 \pm 1.8$ & $97.8 \pm 2.0$ & $94.1 \pm 1.8$ \\
\hline Organic matter [\% d.w.] & $69.0 \pm 0.8$ & $70.4 \pm 0.8$ & $58.4 \pm 1.0$ & $65.8 \pm 0.8$ & $59.6 \pm 0.9$ & $59.7 \pm 0.8$ \\
\hline Phosphorus [mg kg-1 d.w.] & $605 \pm 35$ & $663 \pm 40$ & $864 \pm 43$ & $682 \pm 38$ & $850 \pm 42$ & $784 \pm 41$ \\
\hline Iron [mg kg-1 d.w.] & $3410 \pm 167$ & $1720 \pm 9$ & $1170 \pm 61$ & $777 \pm 42$ & $2030 \pm 99$ & $2060 \pm 103$ \\
\hline Aluminium [mg kg-1 d.w.] & $2030 \pm 100$ & $2500 \pm 115$ & $1530 \pm 78$ & $2080 \pm 103$ & $2280 \pm 115$ & $1750 \pm 89$ \\
\hline Calcium [g kg-1 d.w.] & $5.98 \pm 0.33$ & $148 \pm 11$ & $126 \pm 10$ & $204 \pm 14$ & $11.8 \pm 0.6$ & $90.7 \pm 0.5$ \\
\hline
\end{tabular}

tion period in concentrations below the determinability of the applied analytical method. The whole phosphorus occurred in the organic matter, and was determined as total phosphorus.

In small, shallow water reservoirs, a great role in phosphorus supply is played by the so called "internal source", i.e. bottom sediments. The basic composition of bottom sediments collected from Lake Umultowskie is presented in Table 4. These were organic sediments with a mean content of organic matter of $63.8 \%$. The content of phosphorus in the sediments was not particularly high and amounted to $741 \mathrm{mg} \mathrm{P} \mathrm{kg}^{-1}$ d.w. on average. Much higher phosphorus contents were determined in the bottom sediments of the eutrophic Lake Góreckie in the Greater Poland National Park (Poland). Although the sediments in Lake Góreckie contained much less organic matter, they were characterised by much higher amounts of iron, aluminum and calcium, the metals bonding phosphates in insoluble compounds and locking phosphorus in bottom sediments (Sobczyński and Joniak 2009).

The amount of phosphorus supplying the water depth from bottom sediments is determined not by its

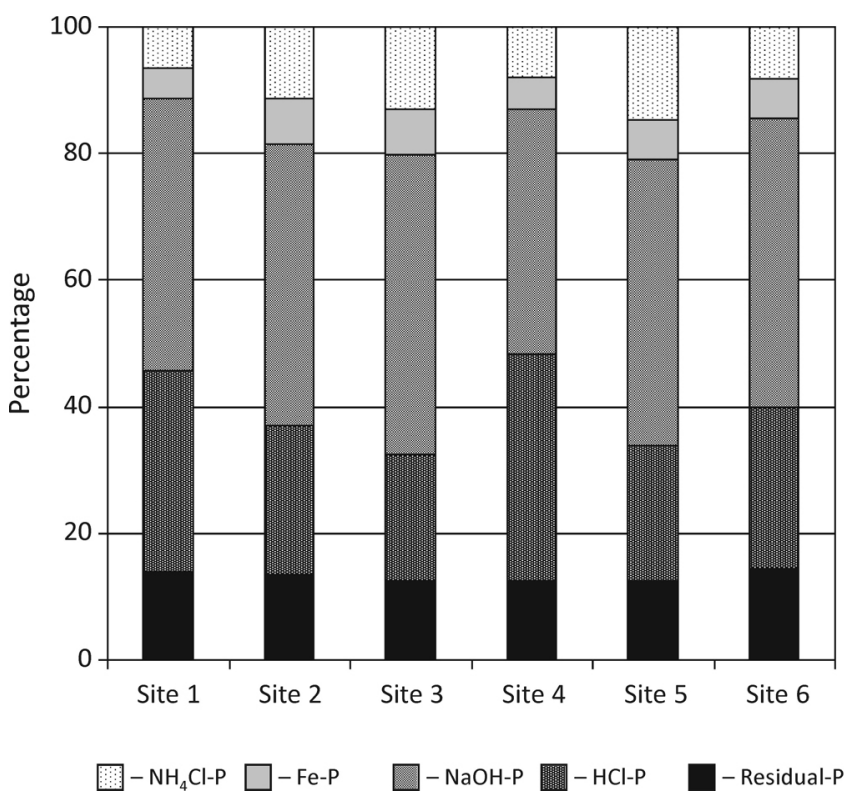

Fig. 2. Percentage contribution of particular phosphorus fractions in its total content in bottom sediments collected at six sites total content in the sediment, but by the content of bioavailable forms, easily released to water. Fractionation of phosphorus by sequential extraction using the Psenner scheme (Psenner et al. 1988; Sobczyński and Joniak 2009) showed that easily bioavailable phosphorus, that is the sum of the first two fractions $-\mathrm{NH}_{4} \mathrm{Cl}-\mathrm{P}$ and $\mathrm{Fe}-\mathrm{P}$, on average constituted $16.4 \%$ of its total content (Fig. 2).

The relatively small content of fraction Fe-P resulted from the fact that the sediments contained little iron. The high contribution of fractions $\mathrm{NaOH}-\mathrm{P}$ and $\mathrm{HCl}-\mathrm{P}$, that is less available fractions, was probably related to the high content of organic matter and calcium (Siwek 2010). The fact that the whole bottom surface of the reservoir is covered by dense meadows of submerged vegetation limited to a large extent the release of phosphates to the water depth, preventing re-suspention of sediments and creating a biological barrier which would screen these compounds out. As a result, the function of limiting the primary production in this ecosystem was taken over by phosphorus.

In order to improve the condition of the lake it would be advisable to mow the submerged vegetation and remove it outside the direct catchment. In this way, large amounts of organic matter can be removed from the lake ecosystem, and along with it - a large load of biogenic elements, mainly nitrogen and phosphorus (Kajak 1998; Bańkowska and Wasilewicz 2008; Pikuła and Heese 2015). Increasing the population of predatory fish, especially pike, should also improve the water quality (Drenner and Hambright 1999; Pikuła and Heese 2015).

The content of determined metals in these sediments was not relatively low. Currently, Poland does not have a legal act defining the norms for admissible metal contents in uncontaminated bottom sediments. Amounts of metals similar to those determined in Lake Umultowskie were also found in the sediments of Lake Jarosławieckie (Sobczyński et al. 1996; Zioła et al. 2005). In the case of $\mathrm{Ni}$ and $\mathrm{Cd}$, their amounts in the sediments of Lake Umultowskie were even smaller. The exception was $\mathrm{Pb}$, whose mean concentration in the sediments of Lake Umultowskie was higher and exceeded the $1^{\text {st }}$ class norm (uncontaminated sediments) by almost three times according to internal criteria used to assess bottom sediments by the Head Inspectorate for Environmental Protection (Bojakowska 2001). 
Table 5. Concentrations of selected metals in the Lake Umultowskie ecosystem (mean values, RSD $<10 \%$ )

\begin{tabular}{|c|c|c|c|c|c|c|}
\hline Specification & $\mathrm{Cd}$ & $\mathrm{Cr}$ & $\mathrm{Cu}$ & $\mathrm{Ni}$ & $\mathrm{Pb}$ & $\mathrm{Zn}$ \\
\hline \multicolumn{7}{|c|}{ Water $\left[\mathrm{mg} \mathrm{dm}^{-3}\right]$} \\
\hline May-October & 0.0015 & 0.003 & 0.004 & 0.005 & 0.001 & 0.025 \\
\hline \multicolumn{7}{|c|}{ Bottom sediments [mg kg-1 d.w.] } \\
\hline Sites 1-6 & 0.5 & 11.2 & 16.0 & 0.9 & 84.8 & 74.3 \\
\hline \multicolumn{7}{|c|}{ Fish muscle tissue $\left[\mathrm{mg} \mathrm{kg}^{-1}\right]$} \\
\hline Rutillus rutillus & 0.05 & 0.1 & 0.4 & 0.1 & 0.7 & 6.9 \\
\hline Blicca bjoerkna & 0.05 & 0.1 & 0.4 & 0.1 & 0.6 & 6.7 \\
\hline \multicolumn{7}{|c|}{ Plants [mg kg ${ }^{-1}$ d.w.] } \\
\hline Phragmites australis (Cav.) Trin. ex Steud. & 0.05 & 1.6 & 2.8 & 0.4 & 3.5 & 8.8 \\
\hline Typha angustifolia L. & 0.05 & 2.0 & 4.9 & 0.8 & 8.2 & 12.8 \\
\hline Carex sp. L. & 0.05 & 1.5 & 4.7 & 0.8 & 13.0 & 17.5 \\
\hline Nymphaea alba L. & 0.05 & 1.1 & 3.1 & 0.2 & 10.0 & 12.0 \\
\hline Ceratophyllum demersum L. & 0.05 & 1.6 & 3.8 & 0.8 & 0.1 & 11.0 \\
\hline
\end{tabular}

The consequences of an increased concentration of lead in bottom sediments were relatively higher - compared with the concentrations of other metals - contents of lead in plants. However, these concentrations were still generally low, for example in comparison with concentrations of this metal in plants collected from Lake Jarosławieckie (Zioła et al. 2005). However, an increased content of lead was found in muscles of fish from Lake Umultowskie, exceeding the admissible value in fish meat intended for consumption (EC 2006).

The increased concentrations of lead in particular elements of the Lake Umultowskie ecosystem are undoubtedly the effect of the influence of urban agglomeration as an increased level of lead concentrations has also been found in the sewage rain water in Poznań (Szpakowska et al. 2014).

\section{Conclusion}

Lake Umultowskie is an example of a small natural water reservoir which, as a result of the expansion of the Poznan agglomeration, has become an urban reservoir. This, however, did not cause the deterioration of its condition. Although the legal protection it was once covered by was cancelled, the diligence of its private owner, and especially in restricting access for anglers, has prevented its condition from deteriorating. In order to improve the state of the lake it would be advisable to seasonally mow the submerged vegetation and remove it outside the direct catchment, eliminating a large load of nitrogen and phosphorus from the lake ecosystem. Increasing the population of predatory fish should also improve the water clarity and landscape value of the lake.

The level of concentrations of cadmium, chromium, copper, nickel and zinc in this ecosystem is relatively low. However, the content of lead in such elements as bottom sediments, vegetation and fish indicates the negative influence of the agglomeration. It is worth not- ing that the lake is situated in an area of single-family housing, at a large distance from the city centre.

\section{Acknowledgements}

The authors would like to thank Ms Karolina Arciszewska, Ms Iga Romanowska, and Ms Patrycja Wojciechowska for their help in conducting the analyses.

\section{References}

Bańkowska A., Wasilewicz M., 2008, Przegląd działań realizowanych w celu poprawy stanu Jeziora Zdworskiego (Undertakings review of the ecological condition improvement in the Zdworskie Lake), Prz. Nauk. Inż. Kszt. Środ. 17(1): 80-90 (in Polish, English summary).

Bedla D., Miszta A., 2014, Zmienność chemizmu wód małych zbiorników wodnych o zróżnicowanej strukturze użytkowania terenów przyległych (Changeability of chemistry of small water reservoirs with diversified use structure of the adjoining areas), Rocz. Ochr. Śr. 16(1): 421-439 (in Polish, English summary).

Bojakowska I., 2001, Kryteria oceny zanieczyszczeń osadów wodnych (Criteria for the assessment of water sediments contamination), Prz. Geol. 49(3): 213-218 (in Polish).

Bolałek J. (ed.), 2010, Fizyczne, biologiczne i chemiczne badania morskich osadów dennych (Physical, biological and chemical studies of marine bottom sediments), Wydaw. UG, Gdańsk, 572 pp (in Polish).

Celewicz-Gołdyn S., Klimko M., 2008, Algal flora of the ecological area "Jezioro Umultowskie” (Lake Umultowskie), [in:] Gołdyn R., Klimaszyk P., Kuczyńska-Kippen N., Piotrowicz R. (eds), The Functioning and Protection of Water Ecosystems Department of Water Protection, Faculty of Biology, Adam Mickiewicz University, Poznań: 17-20.

Drenner W., Hambright K.T., 1999, Biomanipulation of fish assemblages as a lake restoration technique, Archiv Hydrobiol. 146(2): 129-165.

[EC] European Commission, 2006, Commission Regulation (EC) No 1881/2006 of 19 December 2006 setting maxi- 
mum levels for certain contaminants in foodstuffs, Off. J. Eur. Union L. 364: 5-24.

Gołdyn R., Jankowska B., Kowalczak P., Pułyk M., Tybiszewska E., Wiśniewski J., 1996, Wody powierzchniowe Poznania (Surface waters in Poznań), [in:] May J., Stelmasiak S., Kurek L., Ludwiczak I., Niezborała M. (eds), Środowisko naturalne miasta Poznania. Część I (Natural environment of the city of Poznań. Part I), Wyd. WOŚ UM w Poznaniu, Poznań: 45-69 (in Polish).

Hermanowicz W., Dojlido J., Dożańska W., Koziorowski B., Zerbe J., 1999, Fizyczno-chemiczne badania wody i ścieków (Physical-chemical examination of water and wastewater), Wydaw. Arkady, Warszawa, 556 pp (in Polish).

Kajak Z., 1998, Hydrobiologia - Limnologia. Ekosystemy wód śródlądowych (Hydrobiology - limnology, Ecosystems of the inland waters), Wydaw. Nauk. PWN, Warszawa, 360 pp (in Polish).

Klimaszyk P., 2006, Fizyczno-chemiczne i biologiczne właściwości wód użytku ekologicznego „Jezioro Umultowskie" (Physical and chemical water properties of the Lake Umultowskie ecological site) [Typescript], Department of Water Protection UAM, Poznań, 31 pp (in Polish).

Kraska M., Szyszka T., 1985, Roślinność makrofitowa i fitoplankton Jeziora Umultowskiego położonego na terenie planowanej rozbudowy Uniwersytetu im. Adama Mickiewicza w Poznaniu (Macrophyte vegetation and phytoplankton of the Umultowskie Lake located within the planned extension of the University of Adam Mickiewicz in Poznan), Bad. Fizjogr. Pol. Zach. B 36: 105-114 (in Polish).

Niedzielski P, Olejniczak M., Siepak J., 2007, Badania zmienności zawartości tlenu rozpuszczonego w wodzie Jeziora Jelonek w Gnieźnie (Studies of dissolved oxygen variability in the water of Lake Jelonek in Gniezno), Rocz. Ochr. Śr. 9: 457-471 (in Polish).

Paturej E., 2008, Wpływ rekultywacji na trofię jeziora śródmiejskiego (Effect of restoration on the trophic state of an urbane lake), Acta Sci. Pol., Formatio Circumiectus 7(1): 3-12 (in Polish, English summary).

Pikuła K., Heese T., 2015, Metody rekultywacji jezior (Methods of lake recultivation), [in:] Ławniczak A.E. (ed.), Sposoby ochrony i rekultywacji jezior poznańskich (Methods of protection and recultivation of Poznań lakes), Bogucki Wydaw. Nauk., Poznań: 101-107 (in Polish).

Psenner R., Boström B., Dinka M., Pettersson K., Pucsko R., Sager M., 1988, Fractionation of phosphorus in suspend- ed matter and sediment, Arch. Hydrobiol. Beih. Ergebn. Limnol. 30: 98-113.

Siwek H., 2010, Speciation analysis of phosphorus in bottom sediments - comparison of two methods, J. Elem. 15(1): $161-170$.

Sobczyński T., Joniak T., 2008, Zmienność chemizmu wody w profilu pionowym jeziora jako efekt oddziaływania biocenozy i osadów dennych (The water chemistry variablility in lake vertical profile as the effect of biocenosis and bottom sediments interactions), Ekol. Tech. 16(4): 170-176 (in Polish, English summary).

Sobczyński T., Joniak T., 2009, Differences of the composition and contribution of phosphorus fractions in the bottom sediments of Góreckie Lake (Wielkopolska National Park), Environ. Prot. Eng. 35(2): 89-95.

Sobczyński T. , Joniak T., 2013, The variability and stability of water chemistry in deep temperate lake: Results of longterm study of eutrophication, Pol. J. Environ. Stud. 22(1): 227-237.

Sobczyński T., Zerbe J, Elbanowska H., Siepak J., 1996, Badania chemiczne osadów dennych Jeziora Góreckiego w aspekcie oceny oddziaływania antropopresji (Chemical examinations of bottom sediments of Góreckie Lake regarding anthropopression), Ekol. Tech. 2: 14-18 (in Polish).

Szpakowska B., Szczęsna M., Urbański P., Karlik B., 2005, Dynamika stężeń rozpuszczonych azotanów (V) i ortofosforanów (V) w wodach zbiorników aglomeracji wielkomiejskiej (Dynamics of dissolved nitrate (V) and orthophosphate $(\mathrm{V})$ concentrations in waters of urban agglomeration reservoirs), Zesz. Nauk. Wydz. Bud. Inż. Środ. PKosz., Ser. Inż. Środ. 22: 833-842 (in Polish, English summary).

Szpakowska B., Świerk D., Gołdyn R., Barałkiewicz B., 2014, Contents of $\mathrm{Cu}, \mathrm{Zn}, \mathrm{Cd}, \mathrm{Pb}$ and $\mathrm{Fe}$ in rainwater effluents discharged to surface waters in the city of Poznań, J. Elem. 19(3): 779-794.

Urbańska M., Gierszal H., Andrzejewski W., 2015, Krótka historia turystycznej promocji użytków ekologicznych Poznania (Short story of ecological sites for promotion of tourism in Poznań), Stud. Mat. CEPL w Rogowie 17(4): 266-272 (in Polish, English summary).

Zioła A., Szymański M, SobczyńskiT., 2005, Metale ciężkie w wodzie, osadach dennych i roślinach Jeziora Jarosławieckiego, leżącego na terenie Wielkopolskiego Parku Narodowego (Heavy metals in water, bottom sediments and plants collected from Jarosławieckie Lake from area of Wielkopolski National Park), Ekol. Tech. 13(6): 223-227 (in Polish, English summary). 